\title{
Factors Influencing the Dividend Policy of Vietnamese Enterprises
}

\author{
Dang Ngoc Hung (Corresponding author) \\ Faculty of Accounting \& Auditing, Hanoi University of Industry, Vietnam \\ E-mail: toketoankinhte@gmail.com
}

Nguyen Viet Ha

Faculty of Accounting \& Auditing, Hanoi University of Industry, Vietnam

\author{
Dang Thai Binh
}

Vietnam Institute for Indian and Southwest Asian Studies

Vietnam Academy of Social Sciences (VASS)

\begin{abstract}
Received: August 27, 2018 Accepted: Oct. 5, 2018 Published: December 1, 2018
doi:10.5296/ajfa.v10i2.13651 URL: https://doi.org/10.5296/ajfa.v10i2.13651
\end{abstract}

\begin{abstract}
The article explores the factors affecting company's dividend policy such as profitability, firm size, financial leverage and growth rate. Data is collected from enterprises listed on the Vietnam securities market in the period of 2006 - 2017 with 2,150 observations. Using the Generalized Least Squares (GLS), the authors have identified two factors that have a positive and significant effect: (i) return on total assets and (ii) firm size. At the same time, research results also show a negative impact of enterprise's revenue growth rate on the dividend payment ratio. In addition, financial leverage has no impact on company's dividend policy.
\end{abstract}

Keywords: Dividend policy, GLS model, dividend payout ratio; dividend per share ratio 


\section{Introduction}

The aim of dividend policy is to allocate retained earnings for reinvestment and dividends for shareholders. Retained earnings provide investors a source of potential future profit growth through reinvestment, while dividends provide them a current distribution. It determines how much the company's after-tax profit will be distributed, how much retained earnings for reinvestment will be, and how much dividends for shareholders will be. Thus, dividend policy will affect the share of capital in the capital structure of the business and the cost of capital used by the business.

The dividend policy plays an important role in business activities and will be affected by many factors such as profitability, growth rate, firm size, etc. This study focuses on the theories of factors influencing corporate dividend policy and determines how these factors influence the dividend payment decisions of joint stock companies that be listed on the stock market of Vietnam. There have been many studies on the factors influencing the dividend policy in the world, such as Rozeff (1982), Fama \& French (2001), Liu \& Hu, (2005), DeAngelo, DeAngelo, \& Stulz (2006), Nizar Al-Malkawi (2007), Ahmed \& Javid (2008), Gill, Biger, \& Tibrewala (2010). These studies have some similar results but there are also inconsistent results that need to be studied. In Vietnam, the research of Vo (2013), T.M.H. Nguyen, Nguyen, \& Nguyen (2014), Dinh \& Nguyen (2014), T.N.T. Nguyen \& Bui (2018) use different model as well as the dependent variables so the results of the study are not consistent with each other.

The purpose of this study is to clarify the theoretical basis, determine the factors influencing dividend policy (measured by Dividend payout ratio, Dividend Per share ratio) based on empirical research of companies listed in the Vietnam securities market for the period 2006-2017.

\section{Theoretical Framework}

According to Miller \& Modigliani (1961), dividend policy does not affect the value of a company. The value of a company depends on investment decisions. This conclusion of Miller \& Modigliani (1961) is based on the assumptions of an efficient and perfect capital market. This research also relies on customer effect arguments to protect its conclusions. Accordingly, company that change their dividend policy may lose some shareholders because they will move to another company that have an attractive dividend. Thus, stock prices have fallen temporarily, but other investors who prefer the new dividend policy will think that the shares of the company are sold under the price and will buy more shares. Gordon (1963) have a contrast argument with Miller \& Modigliani (1961). He argued that if the assumptions in the M\&M model do not exist, a company's dividend policy becomes more important because it can impact on company value.

Free cash flow theory assumes that company pay dividends to overcome the representative matter which stemming from the separation of ownership and control in a large and dispersed ownership company. In such company, most investors have no ability or incentive to monitor and control all activities of board management. In that case, managers are motivated to engage in activities that may not be in the best interests of the investor. M. C. Jensen (1986) argues that 
paying dividends is the way to achieve this goal. Easterbrook (1984) also has the same argument. According to Jensen (1986), managers have a motivation to expand the company exceeding the optimal scale because the increased size required to increase resources under their control.

Miller \& Rock (1985) suggested that a sudden change in income had a similar effect on corporate profits as a sudden change in dividends. They concluded that income, dividends and donations were closely related. In addition, the current dividend payment trend is the base for market to provide income in the future. Dividend policy is the base for signaling expected income in the future.

A lot of research has been done in this field, but there is not a complete answer. A huge researches have shown that tackling this problem is neither simple nor clear. Dividends which are still one of the most critical issues in corporate finance need to be researched in many aspects

\section{Literature Review}

\subsection{Research in developed countries}

Rozeff (1982) studied the dividend policy and the relationship of dividend policy and variables such as beta coefficient, growth rate, and ownership rate. In this research, the data was collected from 1000 companies in the United States. Results showed that dividend payouts have the opposite effect with future revenue growth, beta coefficient, and ownership rate. In addition, the results of this study also show that dividend policy in a company is affected by investment policy. GR Jensen, Solberg, \& Zorn, et.al, (1992) studied the dividend policy in the US and they concluded that the debt ratio was negatively correlated with the rate of return. When company has higher debt ratio, which means that the greater the financial risk so that company usually pays lower dividends.

Fama \& French (2001) used the logit model with the dependent variable take value 1 if companies pay dividends regularly for ordinary shares every years and value 0 if elsewhere. They point out that the dividends payout ability has positive correlation with firm size, profitability and has a negative relationship with growth opportunities. DeAngelo et al., (2006) extend the analysis of Fama \& French (2001). They include the life cycle measurement of a company and found out that the dividend payout ratio has a positive correlation with the rate of return on book value of common equity and they argue that the rate of return on book value of common equity is often the most important economic indicator influencing to the trend of dividends payout.

Gill et al., (2010) measured the effect of several factors on the dividend payout ratio of companies in the manufacturing and service sectors. In overall sample size, the dividend payout ratio depends on margin profit, revenue growth rate, debt to equity ratio and taxes. For service companies, margin profit, revenue growth rate, and debt to equity ratio are factors that influence the dividend rate of companies. For manufacturing companies, the dividend payout ratio depends on factors such as margins profit, tax and ratio of market value to book value. 


\subsection{Research in developing countries}

Pandey (2001) studied the dividend payment behavior of companies in Malaysia. The sample size was 248 companies from 1993 to 2000 . The results show that there is a difference in dividends payout among sectors in Malaysia. Agricultural and manufacturing companies have a higher dividends payout ratio because they have limited opportunities to invest and increase working capital. This research also shows that profitability, company size and investment opportunities have an influence on dividend policy. A larger company with higher profitability usually pays higher dividends.

Liu \& Hu (2005) studied the dividend policy of companies in China. Samples were randomly selected with 299 companies on the Shanghai Stock Exchange. The results show that dividends payout ratio in Chinese companies are directly related to the earning per share and total assets and have a negative relationship with the debt ratio.

Nizar Al-Malkawi (2007) used Tobit model to determine the factors influencing dividend payout ratio of companies listed on the Jordan Stock Exchange in the period of 1989-2000. Research shows that the stock ownership ratio between people who work in that company and state ownership has a great influence on corporate dividend policy. In addition, firm size, the operating time and profit of the company are also factors that influence the dividends payout ratio.

Ahmed \& Javid (2008) identified the factors affecting the dividend payout ratio of 320 non-financial companies listed on the Stock Exchange Market in Pakistan for the period 2001-2006. Using the Lintner's model (1956), the authors point out that dividend payout ratio depends on the current EPS and dividend payout ratio in the past. However, dividend payouts ratio of these companies are more sensitive to EPS than dividend payouts ratio in the past. In addition, the results of this study also show that companies with high profit and stable EPS have large free cash flow, so they often pay high dividends. Dividend payout ratio is positively correlated with the concentration of ownership and liquidity of the market but it is negatively correlated with the investment opportunity, debt ratio and company size.

Thanatawee (2013) researched dividend policy of companies in Thailand. The study used data from 287 firms listed on the Thailand stock exchanges market for the period 2002-2008. The study found that in Thailand, the dividend payout ratio depends on ROE, firm size, and asset growth rate and financial leverage. He concluded that companies often use bank loans to pay dividends to shareholders.

\subsection{Research in Vietnam}

Vo (2013) conducted a study examining the factors influencing the cash dividend payout ratio with the data of enterprises on Ho Chi Minh Stock Exchange from 2009 to 2012. Research shows that factors such as debt ratio, firm size, tangible fixed assets, growth rate and business risk which have a statistically significant impact on cash dividend payout ratio of companies. In addition, the author indicates that profitability and liquidity do not affect the company's cash dividend payout ratio. 
T. M. H. Nguyen et al., (2014) clarified the theories of factors influencing the dividend policy and determines the effect of these factors on the dividend payment decision. Using the multivariate regression model with the data of 75 companies listed in Vietnam Stock Market for the six years' period from 2007 to 2012, this study shows that profitability, firm size has a significant impact on dividend payout ratio while the growth rate and financial leverage have a negligible impact.

T.N.T. Nguyen \& Bui (2018) examined the determinants of the dividend policy of non-financial companies listed on the Vietnam Stock Market for the period 2008-2015 with the binary dependent variable. This research shows that profitability, the level of money holdings, the liquidity of stocks and the life cycle of companies play an important role in dividends policy. In addition, growth opportunities and financial leverage also have an effect on dividend payments decision. Meanwhile, the other two factors namely the firm size and the risk does not affect the decision.

With these contradictory research results, it is needed to have an explicitly research based on empirical results. In Vietnam, although there have been a number of studies on dividend policy of listed companies in stock market, these research has only provided dividend policy analyzes and factors affecting dividend policy. This study, on the one hand, provides a more accurate assessment of the factors that influence the dividend policy of listed companies in stock market over a long period of time with the dependent variable measured (Dividend payout ratio Dividend Per share ratio). Finally, this study will be based on those assessments to suggest Vietnamese companies to adopt appropriate dividend policy.

\section{Models and Research Methods}

Studying dividend policy in developing and emerging markets shows that dividend policy in emerging market companies is similar to that of US companies. Dividends are affected by profitability, debt ratio, market-to-book ratio (Aivazian, Booth, \& Cleary, 2003). Examining the influencing factors including the effectiveness of business administration, firm size, total assets growth rate, profitability shows that the higher effectiveness of business administration a company have, the higher the dividend will be. In addition, the growth rate negative relationship with the dividend payout ratio.

Profitability: this factor directly affects the company's dividends payment ability (Lintner, 1956). Companies paying high dividend have high profit (Baker \& Powell, 2000 and Nizar Al-Malkawi, 2007). In Vietnam, some studies show that return on total assets (ROA) are positively affect to the company's dividend policy (Dinh \& Nguyen, 2014). Earning Per Share (EPS) is one of the factors that have a positive influence on the dividend decision (T.M.H. Nguyen et al., 2014). Research hypothesis is developed:

\section{H1: Profitability is positively correlated with dividend policy.}

Firm size: Large companies have an easy access to capital market and a low cost capital mobilization because credit institutions believe their repayment capabilities, so it is not necessary to use internal funds. Thus, firm size has an inversely relation with the level of internal fund dependence or large company can pay higher dividends (Al-Yahyaee, Pham, \& 
Walter, 2006; Al-Shubiri, 2011). Meanwhile, the company size has a positive but unpredictable relationship (Mitton, 2004). Research hypothesis is developed:

H2: The firm size has a positive relationship with dividend policy.

Financial leverage: Financial leverage represents the level of corporate loan usage. Loans will cause low dividends payment to maintain a certain amount of capital to meet their debt obligations and to pay for transaction costs (Rozeff, 1982). The adverse effect of financial leverage on dividend has been demonstrated in studies such as Mancinelli \& Ozkan, (2006), Ahmed \& Javid (2008). G. R. Jensen et al. (1992) studied the dividend policy of companies in the United States. They concluded that the debt ratio was negatively correlated with dividend payout ratio. Research hypothesis was developed:

H3: Financial leverage has a negative relationship with dividend policy.

Growth rate: Enterprises with higher growth rates, they will have more investment opportunities, and the managers tend to favor internal capital to conduct all projects with positive net present value, so their dividends are usually low. (GR Jensen et al., 1992). This inverse relationship between growth rate and dividend was demonstrated in the study of Ho (2003) and Al-Yahyaee et al., (2006). Research hypothesis was developed:

H4: The growth rate has a negative relationship with dividend policy.

Based on the previous study model, the author uses the following model:

$$
\begin{gathered}
\text { Dpayout }_{i t}=\beta_{0}+\beta_{1}\left(R_{O} O A_{i t}\right)+\beta_{2}\left(\operatorname{SIZE}_{i t}\right)+\beta_{3}\left(D L F_{i t}\right)+\beta_{4}\left(G R O W_{i t}\right)+\varepsilon_{i t} \\
D P S R_{i t}=\beta_{0}+\beta_{1}\left(R O A_{i t}\right)+\beta_{2}\left(S I Z E_{i t}\right)+\beta_{3}\left(D L F_{i t}\right)+\beta_{4}\left(G R O W_{i t}\right)+\varepsilon_{i t}
\end{gathered}
$$

Table 1. Measurements and expected sign of variables

\begin{tabular}{|c|l|c|l|c|}
\hline No & \multicolumn{1}{|c|}{ Variables } & Code & \multicolumn{1}{|c|}{ Calculation } & $\begin{array}{c}\text { Expected } \\
\text { sign of } \\
\text { Variable }\end{array}$ \\
\hline 1 & Dividend Payout ratio & Dpayout & $\begin{array}{l}\text { Dividend per share /Net income } \\
\text { per share }\end{array}$ & \\
\hline 2 & $\begin{array}{l}\text { Dividend Per share } \\
\text { ratio }\end{array}$ & DPSR & $\begin{array}{l}\text { Dividend per share / Par value } \\
\text { shares }\end{array}$ & \\
\hline 3 & Profitability & ROA & $\begin{array}{l}\text { Net income/ Average total } \\
\text { assets }\end{array}$ & $(+)$ \\
\hline 4 & Firm Size & SIZE & Ln (revenue) & $(+)$ \\
\hline 5 & Financial Leverage & DLF & Debt/Total Assets & $(-)$ \\
\hline 6 & Growth rate & GROW & $\begin{array}{l}\text { (Turnover this period- } \\
\text { Previously Turnover) } \\
\text { (Previous Turnover) }\end{array}$ & $(-)$ \\
\hline
\end{tabular}

Source: Author's establishment 


\section{Macrothink}

Asian Journal of Finance \& Accounting ISSN 1946-052X 2018, Vol. 10, No. 2

The data are collected from companies listed on Ho Chi Minh City stock market for 12 years (2006-2017) with 2150 observations (unbalanced data) and the regression model is based on tabular data.

Regression methods include POOL regression methods, Fixed Effect Model (FEM), and Random Effect Model. After choosing the most appropriate method, the authors conducted a model selection test and a defect assessment test of the selected model. If the defect is violated, the author will use the Generalized Least Squares (GLS).

\section{Results and Discussion}

In the period 2006-2017, the number of enterprises paying cash dividends ranged from $59.9 \%$ to $83 \%$, with an average of $67.6 \%$. Thus, about two-thirds of enterprises pay cash dividends (Table 2).

Table 2. Number of enterprises paying cash dividends yearly

\begin{tabular}{|c|c|c|c|c|c|}
\hline \multirow{2}{*}{ Year } & \multicolumn{2}{|c|}{$\begin{array}{c}\text { Enterprise without cash } \\
\text { dividends payment }\end{array}$} & \multicolumn{2}{c|}{$\begin{array}{c}\text { Enterprise with cash } \\
\text { dividends payment }\end{array}$} & \multirow{2}{*}{ Total } \\
\cline { 2 - 5 } & Quantity & Rate (\%) & Quantity & Rate (\%) & \\
\hline $\mathbf{2 0 0 6}$ & 22 & $31.4 \%$ & 48 & $68.6 \%$ & $\mathbf{7 0}$ \\
\hline $\mathbf{2 0 0 7}$ & 17 & $17.0 \%$ & 83 & $83.0 \%$ & $\mathbf{1 0 0}$ \\
\hline $\mathbf{2 0 0 8}$ & 25 & $20.7 \%$ & 96 & $79.3 \%$ & $\mathbf{1 2 1}$ \\
\hline $\mathbf{2 0 0 9}$ & 20 & $31.3 \%$ & 44 & $68.8 \%$ & $\mathbf{6 4}$ \\
\hline $\mathbf{2 0 1 0}$ & 18 & $20.9 \%$ & 68 & $79.1 \%$ & $\mathbf{8 6}$ \\
\hline $\mathbf{2 0 1 1}$ & 69 & $29.6 \%$ & 164 & $70.4 \%$ & $\mathbf{2 3 3}$ \\
\hline $\mathbf{2 0 1 2}$ & 85 & $35.7 \%$ & 153 & $64.3 \%$ & $\mathbf{2 3 8}$ \\
\hline $\mathbf{2 0 1 3}$ & 81 & $33.5 \%$ & 161 & $66.5 \%$ & $\mathbf{2 4 2}$ \\
\hline $\mathbf{2 0 1 4}$ & 89 & $35.9 \%$ & 159 & $64.1 \%$ & $\mathbf{2 4 8}$ \\
\hline $\mathbf{2 0 1 5}$ & 81 & $33.2 \%$ & 163 & $66.8 \%$ & $\mathbf{2 4 4}$ \\
\hline $\mathbf{2 0 1 6}$ & 83 & $33.2 \%$ & 167 & $66.8 \%$ & $\mathbf{2 5 0}$ \\
\hline $\mathbf{2 0 1 7}$ & 107 & $42.1 \%$ & 147 & $57.9 \%$ & $\mathbf{2 5 4}$ \\
\hline Total & $\mathbf{6 9 7}$ & $\mathbf{3 2 . 4 \%}$ & $\mathbf{1 , 4 5 3}$ & $\mathbf{6 7 . 6 \%}$ & $\mathbf{2 , 1 5 0}$ \\
\hline
\end{tabular}

Source: data extracted from financial statements and calculated from Stata 13.0 by author

Table 3 shows that the average dividend payout ratio is $42.72 \%$, which means that enterprises have used $42.72 \%$ of net profit to pay cash dividend. Average dividend payout ratio was $18.72 \%$ compared to Dividend Per share ratio, the lowest was $0 \%$ and the highest was $660 \%$. Businesses usually pay cash dividends from 1-2 times a year, but in particular there are companies paying cash dividends 5 times a year. Average Return On Assets (ROA) is 6.80\%. The logarithm of total revenue (SIZE) is 13.53, average Financial Leverage (DLF) is $47.13 \%$ and average growth rate (GROW) is $32.86 \%$. 
Table 3. Descriptive Statistic for Variables

\begin{tabular}{lcrrrr}
\hline \multicolumn{1}{c}{ Variable } & \multicolumn{1}{c}{ Obs } & \multicolumn{1}{c}{ Mean } & \multicolumn{1}{c}{ Std. Dev. } & \multicolumn{1}{c}{ Min } & \multicolumn{1}{c}{ Max } \\
\hline Dpayout & 2150 & 0.4272 & 0.4712 & -0.5 & 6.04 \\
DPSR & 2150 & 0.1243 & 0.1968 & 0 & 6.6 \\
ROA & 2150 & 0.0680 & 0.0931 & -1.72 & 0.78 \\
SIZE & 2150 & 13.5388 & 1.3897 & 8.63 & 18.32 \\
DLF & 2150 & 0.4713 & 0.2128 & 0 & 1.06 \\
GROW & 2150 & 0.3286 & 1.3973 & -0.99 & 18.2 \\
\hline
\end{tabular}

Source: data extracted from financial statements and calculated from Stata 13.0 by author

The correlation coefficients matrix among variables is used to analyze and examine the probability of multicollinearity occurrence. Based on the data on table 4, the likelihood of multicollinearity in the regression model is small because most of the correlations among variables are relatively small. None of the cases have the absolute value exceeds 0.6

Table 4. Correlation coefficients matrix

\begin{tabular}{lrrrrrr}
\hline \multicolumn{1}{c}{ Dpayout } & \multicolumn{1}{c}{ DPSR } & \multicolumn{1}{c}{ ROA } & SIZE & DLF & GROW \\
\hline Dpayout & 1 & & & & & \\
DPSR & $0.4279^{*}$ & 1 & & & & \\
ROA & $0.1476^{*}$ & $0.4268^{*}$ & 1 & & & \\
SIZE & $0.0444^{*}$ & $0.1401^{*}$ & $0.1171^{*}$ & 1 & & \\
DLF & $-0.0694^{*}$ & $-0.1365^{*}$ & $-0.3758^{*}$ & $0.3227^{*}$ & 1 \\
GROW & -0.0302 & -0.0042 & $0.0951^{*}$ & $0.0986^{*}$ & 0.0021 & 1 \\
\hline
\end{tabular}

Source: data extracted from financial statements and calculated from Stata 13.0 by author

Based on the regression result (table 5, table 6) with the two dependent variables namely Dividend payout and Dividend per share ratio to consider and select the appropriate model among three regression methods, the author use F and Hausman testing. Using the F test, we see Prob $>F=0.000<\alpha=5 \%$, thus with the significance level of 5 we reject H0. It means that with the data collected, FEM model is appropriate, POOL is inappropriate because of fixed effects existence in each enterprise over time. After selecting the FEM model instead of the POOL method, the authors in turn evaluated the existing tabular data based on FEM and REM. From the FEM and REM results, the Hausman test will be use to compare FEM and REM. Hausman's test results are presented in Table 5, Table 6, which shows that Prob $>$ chi $2=0.0000$ $<5 \%$, thus $\mathrm{H}_{0}$ hypothesis will be rejected. That is the fixed-effects estimation (FEM) is suitable than the random effects estimation (REM). However, before analyzing in detail the factors affecting the dividend policy, the author will use two tests (heteroscedasticity, autocorrelation) and make necessary corrections to overcome restrictions of the model. 
Table 5. Estimation results with Dividend payout ratio

\begin{tabular}{|c|c|c|c|c|c|}
\hline & & POOL & REM & FEM & GLS \\
\hline ROA & 1.28 & $0.273 * *$ & $0.273 * *$ & -0.0806 & $0.681 * * *$ \\
\hline SIZE & 1.21 & $0.0190^{*}$ & $0.0190 *$ & 0.0211 & $0.0149 *$ \\
\hline DLF & 1.39 & -0.0827 & -0.0827 & -0.0275 & -0.0728 \\
\hline GROW & 1.02 & -0.00954 & -0.00954 & -0.00516 & $-0.0159 * *$ \\
\hline cons & & 0.19 & 0.19 & 0.162 & $0.219 * *$ \\
\hline $\mathrm{N}$ & & 2150 & 2150 & 2150 & 2150 \\
\hline R-sq & & 0.1097 & 0.1097 & 0.0017 & \\
\hline \multirow{4}{*}{ LM Test } & & Wald chi2(4) & Wald chi2(4) & \multicolumn{2}{|r|}{ Wald chi2(4) } \\
\hline & & $=13.52$ & $=13.52$ & \multirow{2}{*}{\multicolumn{2}{|c|}{$\begin{array}{c}=\quad 56.33 \\
\text { Prob }>\text { chi } 2\end{array}$}} \\
\hline & & Prob $>$ chi2 & Prob $>$ chi2 & & \\
\hline & & $=\quad 0.0090$ & $=0.0090$ & & $=\quad 0.0000$ \\
\hline \multirow{2}{*}{ F test } & & & \multicolumn{3}{|c|}{$\mathrm{F}(4,1890)=0.58$} \\
\hline & & & \multicolumn{3}{|c|}{ Prob $>F=0.6801$} \\
\hline \multirow{2}{*}{ Hausman test } & & \multicolumn{4}{|c|}{$\operatorname{chi} 2(4)=46.45$} \\
\hline & & \multicolumn{4}{|c|}{ Prob $>$ chi $2=0.0000$} \\
\hline Wooldridge & & \multirow{2}{*}{\multicolumn{4}{|c|}{$\begin{array}{c}\mathrm{F}(1, \quad 252)=4.659 \\
\text { Prob }>\mathrm{F}=0.0318\end{array}$}} \\
\hline test & & & & & \\
\hline Modified & & \multicolumn{4}{|c|}{$\operatorname{chi} 2(256)=4.6 \mathrm{e}+06$} \\
\hline Wald test & & \multicolumn{4}{|c|}{ Prob $>$ chi $2=0.0000$} \\
\hline
\end{tabular}

$\mathrm{t}$ statistics in brackets $* \mathrm{p}<0.1, * * \mathrm{p}<0.05, * * * \mathrm{p}<0.01$

Source: data extracted from financial statements and calculated from Stata 13.0 by author 
Table 6. Estimation results with dividend per share ratio

\begin{tabular}{|c|c|c|c|c|c|}
\hline & VIF & POOL & REM & FEM & GLS \\
\hline ROA & 1.48 & $0.746 * * *$ & $0.746^{* * *}$ & $0.428 * * *$ & $0.878 * * *$ \\
\hline SIZE & 1.23 & $0.0147 * * *$ & $0.0147 * * *$ & $0.0168 * * *$ & $0.0143 * * *$ \\
\hline DLF & 1.38 & 0.00126 & 0.00126 & $0.129 * * *$ & -0.0119 \\
\hline GROW & 1.02 & $-0.00674 * *$ & $-0.00674 * *$ & $-0.00513 *$ & $-0.00755^{* * *}$ \\
\hline cons & & $-0.124 * * *$ & $-0.124 * * *$ & $-0.191 * *$ & $-0.121 * * *$ \\
\hline $\mathrm{N}$ & & 2150 & 2150 & 2150 & 2150 \\
\hline $\mathrm{R}-\mathrm{sq}$ & & 0.6161 & 0.6161 & & \\
\hline \multirow{4}{*}{ LM test } & & Wald chi2(4) & Wald chi2(4) & & Wald chi2(4) \\
\hline & & $=\quad 321.79$ & $=\quad 321.79$ & & $=\quad 515.41$ \\
\hline & & Prob $>$ chi 2 & Prob $>$ chi 2 & & Prob $>$ chi 2 \\
\hline & & $=\quad 0.0000$ & $=\quad 0.0000$ & & $=0.0000$ \\
\hline \multirow{2}{*}{ F test } & & & $\mathrm{F}(4,1890$ & $=21.09$ & \\
\hline & & \multicolumn{4}{|c|}{ Prob $>F=0.0000$} \\
\hline \multirow{2}{*}{ Hausman test } & & \multicolumn{4}{|c|}{$\operatorname{chi} 2(4)=171.65$} \\
\hline & & \multicolumn{4}{|c|}{ Prob $>$ chi $2=0.0000$} \\
\hline \multirow{2}{*}{$\begin{array}{c}\text { Wooldridge } \\
\text { test }\end{array}$} & & \multirow{2}{*}{\multicolumn{4}{|c|}{$\begin{array}{c}F(1, \quad 252)=5.582 \\
\text { Prob }>F=0.0189\end{array}$}} \\
\hline & & & & & \\
\hline Modified & & \multirow{2}{*}{\multicolumn{2}{|c|}{$\begin{array}{c}\operatorname{chi} 2(256)= \\
\text { Prob }>\text { chi } 2=\end{array}$}} & $5.5 e+05$ & \\
\hline Wald test & & & & 0.0000 & \\
\hline
\end{tabular}

To test whether or not the model has heteroscedasticity, the authors used the Breusch and Pagan test. Under the assumption $\mathrm{H}_{0}$ : there is no heteroscedasticity, $\mathrm{H}_{1}$ : there is heteroscedasticity. The P-value received is $0.0000<\alpha(5 \%)$, which implies that there is heteroscedasticity. The Wooldridge test is used to test whether or not the model has autocorrelation. The value $\mathrm{P}$-value $=0.0000<\alpha=0.05$, it means that $\mathrm{H}_{0}$ is rejected so the model has autocorrelation. To overcome these problems, GLS method is used. The results presented in Table 5, Table 6 are the corrected results. Based on Table 8, the results of the study on the factors influencing the dividend policy.

As a result of the GLS model, the return on asset (ROA) is positively correlated with the corporate dividend policy and is statistically significant at $1 \%$. That is suitable with the expected results. This result is consistent with the results of Baker \& Powell (2000), Nizar Al-Malkawi (2007), Nguyen et al. (2014) and T.M. Nguyen et al., (2014). 
Table 7. GLS estimation results

\begin{tabular}{lrr}
\hline & Dividend payout & Dividend per share ratio \\
\hline ROA & $0.681 * * *$ & $0.878^{* * *}$ \\
SIZE & $0.0149 *$ & $0.0143^{* * *}$ \\
DLF & -0.0728 & -0.0119 \\
GROW & $-0.0159 * *$ & $-0.00755^{* * *}$ \\
cons & $0.219^{* *}$ & $-0.121 * * *$ \\
$\mathrm{~N}$ & 2150 & 2150 \\
$\mathrm{R}-\mathrm{sq}$ & 0.1097 & 0.6161 \\
\hline & Source: data extracted from financial statements and calculated from Stata 13.0 by author
\end{tabular}

The results show that the firm size is positively correlated with the Dividend per share ratio (statistically significant at 1\%). This result is consistent with the study of Al-Yahyaee et al., (2006), Al-Shubiri (2011). When considered the dependent variable, Dividend payout ratio is positively related to company size, but the statistically significant is $10 \%$.

The financial leverage is inversely related to dividend policy but is not statistically significant. This is not consistent with the original hypothesis. This finding is not consistent with previous research of Rozeff (1982), Mancinelli \& Ozkan (2006) and Ahmed \& Javid (2008).

As expected, regression results show a statistically significant negative relationship between growth rates and dividend policy. This points to the fact that the demand of capital to finance growth are increasingly and therefore dividends payment is low. In other words, growth companies have more investment opportunities, so businesses are more likely to pursue a lower dividend payout ratio as dividends and investments represent two competing object to use company's cash. The results of this study are consistent with the results of Ho (2003) and Al-Yahyaee et al., (2006).

The results of the regression show that profitability, previous dividend payout ratio, financial leverage and growth rates have an impact to the dividend policy with statistical significance:

(1) The profitability has a positive impact on the dividend policy of company listed on the securities market of Vietnam. This may explain that company with good profitability will pay dividends to shareholders. At the same time, the previous dividend policy has a positive impact on the dividend policy of the next period, however, the company size does not affect the dividend policy.

(2) Financial leverage has a negative impact on dividend policy of enterprises listed on the securities market of Vietnam. This can be explained that the higher the debt rate is higher the risk. When the cost of capital is high, the business must pay attention to the debt payment rather than dividends payment. 


\section{Conclusions and Recommendations}

Dividend policy is one of the three important decisions of financial management. Based on the results of this study, the authors propose some recommendations:

(i) Investors need to study the financial status of the business as the profitability because it will affect to the dividends payment of the next period. High debt ratio will negatively affect dividend payment.

(ii) The manager should have an analysis of the advantages and disadvantages of each type of dividend policy and consider which one will be suitable with the specific characteristics of company. Most importantly, managers have a clear choice of dividends policy and pursue that choice. Because, in order to maintain dividend payments, it is imperative for managers to have a long-term financial and investment strategy, a more responsible for raising capital efficiency, helping to increase the company value in the long run.

(iii) Enterprises should prioritize stable dividend policy to maintain a certain level of dividends and increase dividends to a higher level only in the case that the company can achieve a stable increased profitability and have an ability to increase dividend. Once the dividend has been increased, company must try to maintain this dividend level until the company sees that there is no hope to prevent a decline in profitability in the future.

\section{References}

Ahmed, H., \& Javid, A. Y. (2008). Dynamics and determinants of dividend policy in Pakistan (evidence from Karachi stock exchange non-financial listed firms). International Research Journal of Finance and Economics, 25(1), 148-171.. https://mpra.ub.uni-muenchen.de/37342/

Aivazian, V., Booth, L., \& Cleary, S. (2003). Do emerging market firms follow different dividend policies from US firms? Journal of Financial research, 26(3), 371-387. https://doi.org/10.1111/1475-6803.00064

Al-Shubiri, F. N. (2011). Determinants of changes dividend behavior policy: Evidence from the Amman Stock Exchange. Far East Journal of Psychology and Business, 4(1), 1-15.

Al-Yahyaee, K., Pham, T., \& Walter, T. (2006). Dividend Policy in the Absence of Taxes. School of Banking and Finance, University of New South Wales.

Baker, H. K., \& Powell, G. E. (2000). Determinants of corporate dividend policy: a survey of NYSE firms. Financial Practice and education, 10, 29-40.

Baker, H. K., Powell, G. E., \& Veit, E. T. (2002). Revisiting the dividend puzzle: Do all of the pieces now fit? Review of Financial Economics, 11(4), 241-261. https://doi.org/10.1016/S1058-3300(02)00044-7

DeAngelo, H., DeAngelo, L., \& Stulz, R. M. (2006). Dividend policy and the earned/contributed capital mix: a test of the life-cycle theory. Journal of financial economics, 81(2), 227-254. https://doi.org/10.1016/j.jfineco.2005.07.005 
Đinh, B. N., \& Nguyễn, C. C. (2014). Các nhân tố ảnh hưởng đến chính sách cổ tức của các doanh nghiệp niêm yết trên thị trường chứng khoán VN. Tạp chí Phát triển kinh tế, 290(1), 42-60.

Easterbrook, F. H. (1984). Two agency-cost explanations of dividends. The American economic review, 74(4), 650-659.

Fama, E. F., \& French, K. R. (2001). Disappearing dividends: changing firm characteristics or lower propensity to pay? Journal of financial economics, 60(1), 3-43. https://doi.org/10.1016/S0304-405X(01)00038-1

Gordon, M. J. (1963). Optimal investment and financing policy. The journal of finance, 18(2), 264-272.

Gill, A., Biger, N., \& Tibrewala, R. (2010). Determinants of dividend payout ratios: evidence from United States. The Open Business Journal, 3(1), 4-14. https://doi.org/10.2174/1874915101003010008

Ho, H. (2003). Dividend policies in Australia and Japan. International Advances in Economic Research, 9(2), 91-100. https://doi.org/10.1007/BF02295710

Jensen, G. R., Solberg, D. P., \& Zorn, T. S. (1992). Simultaneous determination of insider ownership, debt, and dividend policies. Journal of Financial and Quantitative analysis, 27(2), 247-263. https://doi.org/10.2307/2331370

Jensen, M. C. (1986). Agency costs of free cash flow, corporate finance, and takeovers. The American economic review, 76(2), 323-329.

Lintner, J. (1956). Distribution of incomes of corporations among dividends, retained earnings, and taxes. The American economic review, 46(2), 97-113.

Liu, S., \& Hu, Y. (2005). Empirical analysis of cash dividend payment in Chinese listed companies. Nature and Science, 1(3), 65-70.

Mancinelli, L., \& Ozkan, A. (2006). Ownership structure and dividend policy: Evidence from Italian firms. European Journal of Finance, 12(03), 265-282. https://doi.org/10.1080/13518470500249365

Miller, M. H., \& Modigliani, F. (1961). Dividend policy, growth, and the valuation of shares. The Journal of Business, 34(4), 411-433. https://doi.org/10.1086/294442

Miller, M. H., \& Rock, K. (1985). Dividend policy under asymmetric information. The journal of finance, 40(4), 1031-1051. https://doi.org/10.1111/j.1540-6261.1985.tb02362.x

Mitton, T. (2004). Corporate governance and dividend policy in emerging markets. Emerging Markets Review, 5(4), 409-426. https://doi.org/10.1016/j.ememar.2004.05.003

Nizar Al-Malkawi, H.-A. (2007). Determinants of corporate dividend policy in Jordan: an application of the Tobit model. Journal of Economic and Administrative Sciences, 23(2), 44-70. https://doi.org/10.1108/10264116200700007 


\section{Macrothink}

Asian Journal of Finance \& Accounting ISSN 1946-052X

Nguyễn, T. M. H., Nguyễn, T. T. D., \& Nguyễn, T. T. L. (2014). Những nhân tố ảnh hưởng đến chính sách chi trả cổ tức của các công ty cổ phần tại Việt Nam. Tạp chí Kinh tế \& Phát triển, 210(1), 33-42.

Nguyễn, T. N. T., \& Bùi, K. P. (2018). Nghiên cứu các yếu tố quyết định đến chính sách chi trả cổ tức bằng kĩ thuật hồi quy Fama - MacBeth: Bằng chứng thực nghiệm tại Việt Nam. Phát triển kinh tế, 28(9), 4-24.

Pandey, I. M. (2001). Corporate dividend policy and behaviour: the Malaysian experience. Working Paper (1-21).

Rozeff, M. S. (1982). Growth, beta and agency costs as determinants of dividend payout $\begin{array}{llll}\text { ratios. Journal of Financial } & \text { research, } & 5(3), 259 .\end{array}$ https://doi.org/10.1111/j.1475-6803.1982.tb00299.x

Thanatawee, Y. (2013). Ownership structure and dividend policy: Evidence from Thailand. International Journal of Economics and Finance, 5(1), 121-132.

Võ, X. V. (2013). Các yếu tố tác động đến chính sách cổ tức bằng tiền mặt. Tạp chí Kinh tế \& Phát triển, 210(1), 36-43. 